\title{
Development of Entrepreneurial Skill Manual on Aloe Vera Production for Training Farmers in Benue State Nongugwa $\mathrm{DT}^{1 *}$ and Asogwa $\mathrm{VC}^{2}$
}

${ }^{1}$ Department of Agricultural Education, Federal University of Agriculture, Makurdi, Nigeria

${ }^{2}$ Department of Agriculture/Home Economics, Micheal Okpara University of Agriculture, Umudike, Abia State, Nigeria

\begin{abstract}
This study was on development of entrepreneurial skills manual in aloe vera production for training farmers in Benue State. Specific objectives for the study were to: identify the objectives for aloe vera production, determine the content of aloe vera production manual for achieving the objectives for farmers, determine the training methods required by trainers in teaching aloe vera production to farmers, identify the facilities required for training farmers in aloe vera production, determine the evaluation techniques for assessing farmers' achievement of objectives of aloe vera production in Benue state. Five research questions were raised and answered; five hypotheses were formulated and tested at $\mathrm{P} \leq 0.05$ level of significance. The design for the study was survey research design. The population for the study was 201 made up of 59 lecturers from University of Agriculture Makurdi and 142 extension agents in Benue State. The entire population was involved by means of census. An instrument titled: Aloe Vera Entrepreneurial Skills Production Questionnaire (AESPQ) developed by the researchers from literature reviewed and their experience. Mean was used to answer the research questions, while t-test was used to test the null hypotheses at $P \leq 0.05$ level of significance. The findings of the study revealed that: that 9 objectives of aloe vera production are required for training farmers in Benue State, 65 cluster items formed the content of aloe vera production manual for achieving the objectives for farmers in Benue State, eight methods required for training farmers in aloe vera production, 17 facilities for training farmers in aloe vera production and 6 techniques for assessing farmers achievement of the objectives for aloe vera production manual in Benue State. It was therefore recommended that Agricultural Extension agents should regularly organize seminars and workshops for training of farmers and retraining of graduates to improve their technical efficiency using this manual, researchers should use the manual emanating from this study as a reference material for further research among others.
\end{abstract}

Keywords: Aloe vera; Entrepreneurial skills; Manual development; Agricultural extension agents; Farmers

\section{Introduction}

A crop is a cultivated plant whose product is harvested by humans at a stage of its development [1]. Some of these crops have some properties that give them the ability to heal certain poisons, disease or nutritional deficiencies when consumed at the right time, form and quantity. These crops produce many chemical compounds for biological functions such crops as aloe vera.

Aloe vera Aloe spp. is a succulent African plant of the genus Aloe and family Aloeaceae having rosettes of leaves usually with fiber like hemp and spikes of showy flowers [2]. It is a very short-stemmed plant with thick leaves, with soothing mucilaginous juice. Its leaves develop spiny margins with maturity; and native to Mediterranean region. It is grown widely as houseplants.

Nutritionally, aloe vera contains many minerals vital to the growth process and healthy function of all the body's systems [3]. The constituents in aloe vera are Vitamins, Minerals, Sugars, Enzymes, Lignins, Amino Acids, Anthraquinones, Saponins, Fatty Acids, Salicylic Acid, the organization maintained. According to Karkala and Bhushan [2], vegetables are good source of minerals (especially calcium and iron), vitamins and dietary fibre. Aloe vera is one of the known natural vegetable sources of Vitamin B12. They however explained that it appears there are only trace amounts of B12 at best in aloe vera and taking aloe vera at the same time as a Vitamin B12 supplement increases the absorption and bio-availability of the B12 to the body. It is therefore a great addition to daily regime as it helps adults, children, and even pets receive more value from their foods and supplements. These accrued benefits of aloe vera attract farmers to its production.
A farmer as reported by Central Bank of Nigeria [4] is a person who engages in agriculture; raising living organisms for food or raw materials. Farmers are individuals who are engaged in any form of animal or crop production. In this regard, farmers are individuals who cultivate aloe vera either for commercial or subsistence use. The farmers are guided by extension agents in analyzing and solving their farm problems. Agricultural Extension Agents according to Ogunbameru [5] are individuals, who help farmers experiment with new technologies or with new farming systems, evaluate and interprets information for their own situation among other functions. These Agricultural extension agents are taught either in mono-technics, polytechnics and colleges of education or universities by lecturers. The lectures transfer knowledge, competencies and skills to these agricultural extension agents in such a way that they will understand and transfer same to others.

National Policy on Education in Asogwa et al. [6] stated that, a lecturer is a person who had undergone approved professional training in education at appropriate levels and is capable of imparting knowledge, skills and attitudes to the learners in a relevant programme.

*Corresponding author: Nongugwa DT, Department of Agricultural Education, Federal University of Agriculture, Makurdi, Nigeria, Tel: +234- 08111753334 E-mail: Nongugwa2011@gmail.com

Received December 11, 2017; Accepted December 19, 2017; Published December 26, 2017

Citation: Nongugwa DT, Asogwa VC (2017) Development of Entrepreneurial Skill Manual on Aloe Vera Production for Training Farmers in Benue State. Int J Waste Resour 8: 319. doi: 10.4172/2252-5211.1000319

Copyright: ( 2017 Nongugwa DT, et al. This is an open-access article distributed under the terms of the Creative Commons Attribution License, which permits unrestricted use, distribution, and reproduction in any medium, provided the original author and source are credited. 
In this study, a lecturer is a person who has acquired training in teaching methodology and technical aspects of a programme in a university and inculcates same to other individuals who serve as Agricultural Extension Agents in the society. The Agricultural Extension Agents are equipped with skills and competencies in agricultural practices for crop production such as pre-planting, planting, harvesting among other.

The way farmers in Benue State go about aloe vera production, that is, they don't provide the crops with the correct and timely agricultural practices such as proper handling during transplanting from the nursery to the field, supplying the plants with water during dry season, they rather allow the crops to thrive for survival thereby yielding very low. The researchers are on the opinion that, if these farmers are provided with the skills required for aloe vera production, they can improve their efficiency in production. This could be achieved through development of a skill training manual for the production of aloe vera.

A manual as explained by Rama et al. [7] is a compilation of segments of instruction for achieving a particular task. A manual is a booklet of instructions containing information and guidelines to educate the user on how to perform a specific task. Skill manual is therefore a booklet of instructions on specific abilities and a step by step approach in performing a task. It shows a step by step arrangement of learning experiences that indicates which activity to follow which one starting from simple to complex and known to the unknown. Manuals developed in this pattern aid and facilitate teaching and learning.

Manual development is considered as an organized sequence of several steps and actions geared towards a skill or task. It is an outline of the task to be accomplished in a sequence that permits maximal achievement of the objectives for which it is produced. The procedure for manual development according to Wever [8], involves the selection of the needs and knowledge to be taught (these make up the training objectives) and organizing the selected skills and knowledge into suitable training units. In the context of this study, development of entrepreneurial skills manual involves the identification of the objectives, careful selection of the content (that is, skills for aloe vera production), method and facilities for aloe vera production and finally the techniques for evaluating the achievement of the objectives for aloe vera production.

In Benue State of Nigeria in particular and the nation at large, in spite of the nutritional, medicinal and economic values accruable from aloe vera production, most farmers do not engage in its production. It was observed by the researcher that, farmers in many communities in the state do not produce aloe vera on commercial basis. Even those who produce allow the crops grow on their own. The situation seemed worrisome since it was suspected to be associated with lack of entrepreneurial skills required for its production since it is not an indigenous crop plant. Besides, a visit by the researchers to the Benue State Agricultural and Rural Development Authority (BENARDA) and other Skill Acquisition Centres (SAC) in Benue State revealed that, there are identified skills or skill packaged programmes in training interested individuals in areas such as cassava production, pig production, maize production among others, but there was none on aloe vera production for the training of interested individuals in the State.

Will the development of entrepreneurial manual help in training interested farmers in aloe vera production? Will the training of interested individuals in aloe vera boost aloe vera production? It was based on this that the researchers were motivated to undertake a study on the development of an entrepreneurial skill manual in aloe vera production for training farmers, thereby fostering its optimum commercial benefits for the improvement of their wellbeing in Benue State. Hence, the purpose of this study is the development of an entrepreneurial Skill manual in aloe vera production for training farmers in Benue State. Specifically the study sought to:

1. Determine the objectives of aloe vera production manual for farmers in Benue State.

2. Identify the content of aloe vera production manual for achieving the objectives for farmers in Benue State.

3. Determine the training methodology required by trainers in teaching aloe vera production to farmers in Benue State.

4. Identify the facilities required for training farmers in aloe vera production in Benue State.

5. Determine the evaluation techniques for assessing farmers achievement of objectives of aloe vera production in Benue state.

\section{Methodology}

\section{Research questions}

The following research questions were developed to be answered by the study.

1. What are the objectives of aloe vera production for farmers in Benue State?

2. What is the content of aloe vera production manual for achieving the objectives of aloe vera production for farmers in Benue State?

3. What is the training methodology required by trainers in teaching aloe vera production to farmers in Benue State?

4. What are the facilities required for training farmers in aloe vera production in Benue State?

5. What are the evaluation techniques for assessing farmers' achievement of objectives of aloe vera production in Benue state?

\section{Hypotheses}

There is no significant difference between the mean rating of responses of lecturers and extension agents on:

1. Objectives of aloe vera production for farmers in Benue State.

2. Content of aloe vera production manual for achieving the objectives of aloe vera production for farmers in Benue State.

3. Training methodology required by trainers in teaching aloe vera production to farmers in Benue State.

4. Facilities required for training farmers in aloe vera production in Benue State.

5. Evaluation techniques for assessing farmers' achievement of objectives of aloe vera production in Benue state.

Five research questions were raised and answered by the study, five hypotheses were formulated and tested at 0.05 level of significance. Survey research design was adopted for the study. This design was considered appropriate for the study because the views of a representative of the respondents were obtained using questionnaire and the findings were generalized upon the entire population. The study was conducted in Benue State consisting of three Agricultural Zones namely: Zone A, $\mathrm{B}$ and $\mathrm{C}$. The population of the study was 201 made up of 59 lecturers 
from University of Agriculture Makurdi and 142 extension agents in Benue State. The entire population was involved by employing a census study. An instrument titled: aloe vera Entrepreneurial Skills Production Questionnaire (AESPQ) developed by the researcher from literature reviewed and experience of the researchers. The questionnaire was divided into part A and B. Part A sought information on the personal data of the respondents. Part B had five sections (1-5) which was used to collect information on: objectives of aloe vera production manual for farmers, content of aloe vera production manual for achieving the objectives, training methodology required by trainers teaching aloe vera production, facilities required for training farmers and evaluation techniques for assessing farmers' achievement of the objectives of aloe vera production in Benue state using a four point rating scale of Highly Required (HR), Averagely Required (AR), Slightly Required (SR), Not Required (NR). Each of the response options had had a corresponding value of 4, 3, 2 and 1 respectively. The instrument was subjected to face and content validity by three experts, two from the Department of Agricultural Education and one from the Department of Science Education all from the University of Agriculture Makurdi, Benue State. The experts from agricultural education were selected based on their knowledge and skills in aloe vera production while those from science education were selected based on knowledge on questionnaire development. Validates checked the facial appearance, clarity of language for face validity, relatedness of the items, appropriateness of the content coverage, suitability of items for content validity. Irrelevant and ambiguous questionnaire items were removed while others were reviewed according to the objectives of the study, research questions and hypothesis. The validated questionnaire was administered to fifteen respondents: ten lecturers and five extension agents in Nasarawa State. This is because; the sample has similar characteristics with the study sample. The collected data were used to ascertain the reliability of the instrument. Crombach Alpha formula was used for the reliability and a reliability coefficient of 0.91 was obtained meaning that the instrument was highly reliable for the study.

Three research assistants who were familiar with the area of study were selected and given orientation on how to administer to and retrieve copies of the questionnaire from the respondents (lecturers and Agricultural Extension Agents). Two hundred and one copies of the questionnaire were administered to the respondents; collection was done immediately after checking the items. After four days of administration, a follow-up visit was embarked on to those who delayed responding to the questionnaire to remind them and possibly collect it. A total of 196 copies of the questionnaire were returned.

Data collected were analyzed using arithmetic mean and standard deviation to answer the research questions and t-test statistics was used to test the null hypotheses at 0.05 level of significance. In testing the hypotheses, a null hypothesis of no significant difference was not rejected where p-value was equal or greater than the alpha value of 0.05 but rejected where p-value was less than the alpha value of 0.05 .

\section{Results}

The results for the study were obtained from the research questions answered and hypotheses tested through data collected and analyzed. The results for answering research questions and testing the hypotheses is presented in Tables 1-5.

Data in Table 1 revealed that all the 9 items had their mean values ranged from 2.86 to 3.93 which were above the bench mark of 2.50 . The table also revealed that the standard deviations (SD) of the items ranged from 0.26 to 0.96 which indicated that the respondents were not very far from the mean and one another in their responses. This showed that all the 9 items were objectives of aloe vera production manual for training farmers in Benue State. The hypothesis tested revealed further that all the 9 items had their p-values greater than the alpha value. This indicates that there was no significant difference in the mean rating of the two groups of respondents (Lecturers and Agricultural Extension Agents) on the objectives of aloe vera production manual for training farmers in Benue State. This indicated that there was no statistical significant difference in the mean rating of the two groups of respondents on the objectives of aloe vera production manual for training farmers in Benue State. Therefore, the null hypothesis of no significant difference was not rejected for all the items.

Data in Table 2 revealed that all the 46 cluster items had their mean values ranged from 3.32 to 3.65 which were above the bench mark of 2.50. The table also revealed that the standard deviations (SD) of the items ranged from 0.71 to 0.81 which indicated that the respondents were not very far from the mean and one another in their responses. This showed that all the 6 items were content of aloe vera production manual for training farmers in Benue State. The hypothesis tested revealed further that all the 46 cluster items had their p-values greater than the alpha value. This indicates that there was no significant difference in the mean rating of the two groups of respondents (Lecturers and Agricultural Extension Agents) on the content of aloe vera production manual for training farmers in Benue State. This indicated that there was no statistical significant difference in the mean rating of the two groups of respondents on the content of aloe vera production manual for training farmers in Benue State. Therefore, the null hypothesis of no significant difference was not rejected for all the items.

Data in Table 3 revealed that all the 8 items had their mean values ranged from 3.00 to 3.59 which were above the bench mark of 2.50 The table also revealed that the standard deviations (SD) of the items ranged from 0.61 to 0.93 which indicated that the respondents were not very far from the mean and one another in their responses. This showed that all the 8 items were training methods used for training farmers in

\begin{tabular}{|c|c|c|c|c|c|}
\hline S/No. & At the end of this manual the trainees should be able to: & Mean & SD & Pvalue & Remark \\
\hline 1 & Set up a plan for Aloe Vera production & 3.93 & 0.26 & 0.827 & NR, NS \\
\hline 2 & Select breeds of Aloe Vera to cultivate & 3.46 & 0.81 & 0.825 & NR, NS \\
\hline 3 & Establish an enterprise in Aloe Vera production & 3.73 & 0.44 & 0.905 & NR, NS \\
\hline 4 & Cultivate Aloe Vera to maturity stage & 3.73 & 0.45 & 0.904 & NR, NS \\
\hline 5 & Harvest Aloe Vera to market for consumers & 3.33 & 0.60 & 0.925 & NR, NS \\
\hline 6 & Process harvested Aloe Vera to variety of products & 2.87 & 0.96 & 0.926 & NR, NS \\
\hline 7 & Store processed Aloe Vera & 2.86 & 0.89 & 0.752 & NR, NS \\
\hline 8 & Market Aloe Vera products & 3.20 & 0.91 & 0.751 & NR, NS \\
\hline 9 & Identify records to be kept in Aloe Vera production & 3.27 & 0.77 & 0.766 & NR, NS \\
\hline
\end{tabular}

Note: $\mathrm{SD}=$ Standard Deviation, NR=Not Required, NS= Not Significant, $\mathrm{P} \leq 0.05, \mathrm{t}-\mathrm{cri}=1.96$

Table 1: Mean rating and t-test analysis of respondents on the objectives of aloe vera production manual for training farmers in Benue state ( $\mathrm{N}=196)$. 


\begin{tabular}{|c|c|c|c|c|c|}
\hline S/NO & Content of Aloe Vera Manual (Clusters) & Mean & SD & p-value & Remark \\
\hline 1 & Skills in Planning for Ale Vera production (12 items) & 3.39 & 0.71 & 0.39 & NR, NS \\
\hline 2 & Skills in pre- planting operations (15 items) & 3.36 & 0.81 & 0.67 & NR, NS \\
\hline 3 & Skills in planting operations ( 7 items) & 3.41 & 0.79 & 0.80 & NR, NS \\
\hline 4 & Skills in post planting operations ( 5 items) & 3.65 & 0.65 & 0.81 & NR, NS \\
\hline 5 & Skills in post-harvest and marketing operations (16 items) & 3.32 & 0.76 & 0.75 & NR, NS \\
\hline 6 & Skills in record keeping (10 items) & 3.43 & 0.81 & 0.87 & NR, NS \\
\hline
\end{tabular}

Note: $\mathrm{SD}=$ Standard Deviation, NR=Not Required, NS= Not Significant, $\mathrm{P} \leq 0.05, \mathrm{t}$-cri=1.96

Table 2: Mean rating and t-test analysis of respondents on the content of aloe vera production manual for training farmers in Benue state ( $n=196)$.

\begin{tabular}{|c|c|c|c|c|c|}
\hline S/NO & Training methods & Mean & SD & p-value & Remark \\
\hline 1 & Lecture & 3.40 & 0.71 & 0.90 & NR, NS \\
\hline 2 & Role play & 3.59 & 0.71 & 0.90 & NR, NS \\
\hline 3 & Discussion & 3.40 & 0.88 & 0.90 & NR, NS \\
\hline 4 & Demonstration (result and method) & 3.53 & 0.81 & 0.89 & NR, NS \\
\hline 5 & Brainstorming & 3.27 & 0.93 & 0.43 & $\mathrm{NR}, \mathrm{NS}$ \\
\hline 6 & Discovery & 3.00 & 0.73 & 0.41 & NR, NS \\
\hline 7 & Excursion/field trip & 3.27 & 0.85 & 0.66 & NR, NS \\
\hline 8 & Project method & 3.59 & 0.61 & 0.64 & NR, NS \\
\hline
\end{tabular}

Note: $\mathrm{SD}=$ Standard Deviation, NR=Not Required, NS= Not Significant, $\mathrm{P} \leq 0.05$, $\mathrm{t}$-cri=1.96

Table 3: Mean rating and t-test analysis of respondents on the training methods required by trainers in teaching aloe vera production to farmers in Benue state ( $\mathrm{n}=196)$

Benue State. The hypothesis tested revealed further that all the 8 items had their p-values greater than the alpha value. This indicates that there was no significant difference in the mean rating of the two groups of respondents (Lecturers and Agricultural Extension Agents) on the training methods used for training farmers in aloe vera production in Benue State. This indicated that there was no statistical significant difference in the mean rating of the two groups of respondents on the training methods used for training farmers in Benue State. Therefore, the null hypothesis of no significant difference was not rejected for all the items.

Data in Table 4 revealed that all the 17 items had their mean values ranged from 3.13 to 3.67 which were above the bench mark of 2.50 . The table also revealed that the standard deviations (SD) of the items ranged from 0.62 to 1.05 which indicated that the respondents were not very far from the mean and one another in their responses. This showed that all the 17 items were facilities used for training farmers in aloe vera production in Benue State. The hypothesis tested revealed further that all the 18 items had their $\mathrm{p}$-values greater than the alpha value. This indicates that there was no significant difference in the mean rating of the two groups of respondents (Lecturers and Agricultural Extension Agents) on the facilities used for training farmers in aloe vera production in Benue State. This indicated that there was no statistical significant difference in the mean rating of the two groups of respondents on the facilities used for training farmers in aloe vera production in Benue State. Therefore, the null hypothesis of no significant difference was not rejected for all the items.

Data in Table 5 revealed that all the 10 items had their mean values ranged from 3.13 to 3.53 which were above the bench mark of 2.50 . The table also revealed that the standard deviations (SD) of the items ranged from 0.61 to 1.05 which indicated that the respondents were not very far from the mean and one another in their responses. This showed that all the 10 items were evaluation techniques for assessing farmers' achievement of objectives of aloe vera production in Benue State. The hypothesis tested revealed further that all the 10 items had their $p$-values greater than the alpha value. This indicates that there was no significant difference in the mean rating of the two groups of respondents (Lecturers and Agricultural Extension Agents) on the evaluation techniques for assessing farmers' achievement of objectives of aloe vera production in Benue State. This indicated that there was no statistical significant difference in the mean rating of the two groups of respondents on the evaluation techniques for assessing farmers' achievement of objectives of aloe vera production in Benue State. Therefore, the null hypothesis of no significant difference was not rejected for all the items.

\section{Discussion}

The finding of the study shows that 9 objectives of aloe vera production are required for training farmers in Benue State. The objectives are set up a plan for aloe vera production, select breeds of aloe vera to cultivate, establish an enterprise in aloe vera production, cultivate aloe vera to maturity stage, harvest aloe vera to market for consumers, process harvested aloe vera to variety of products, and store processed aloe vera in refrigerated facility, among others. The findings were in agreement with the submission of Jones [9] who stated that, objectives of a farm business include: setting up a plan for production, processing and marketing. Also that, records should be kept in all segments of the farm enterprise.

The finding of the study also show that the content of aloe vera production manual include measure out spacing of $60 \mathrm{~cm}$ between rows and $60 \mathrm{~cm}$ within rows, make holes of $3 \mathrm{~cm}$ deep, $0.5 \mathrm{~cm}$ wide with stick, place the suckers in the holes made, apply organic manure to the farm after four weeks of planting, mulch the base of the suckers with grasses and leaves, weed off grasses on the farm regularly with hoe to avoid competition with the crop, apply water regularly depending on the soil moisture content, spray appropriate pesticides for pest control (using knapsack sprayer). The findings were in consonance with Ugwoke et al. [10] on occupational competencies required by retirees in pawpaw production and marketing for sustainable livelihood in Enugu state, Nigeria who recommended ploughing and harrowing the site to pulverize the soil for easy root development, transplanting one or two seedlings per hole when using a dioecious variety to ensure a high female survival, survey the land for proper demarcation among others. The findings of the study also agree with submission of Rajeswari et al [11] that, aloe vera suckers are planted in about $15 \mathrm{~cm}$ deep pits made just at the time of planting at $60 \times 60 \mathrm{~cm}$ apart, during the first year of plantation,FYM@20 t/ha is applied at the time of land preparation and 


\begin{tabular}{|c|c|c|c|c|c|}
\hline S/NO & Training facilities & Mean & SD & p-value & Remark \\
\hline 1 & Cutlass for clearing of grasses and shrubs. & 3.47 & 0.89 & 0.77 & NR, NS \\
\hline 2 & Pick axe for felling trees and stumping & 3.67 & 0.70 & 1.00 & NR, NS \\
\hline 3 & Rake for gathering of leaves, grasses and leveling seed beds & 3.40 & 0.71 & 1.00 & NR, NS \\
\hline 4 & Hoe for tilling and weeding of grasses. & 3.60 & 0.71 & 0.98 & NR, NS \\
\hline 5 & Spade and digging fork to thrust vertically into soil & 3.54 & 0.72 & 0.98 & NR, NS \\
\hline 6 & Hand trowel, dibbler, jabstyle planters for transplanting and manure application. & 3.33 & 0.95 & 0.85 & NR, NS \\
\hline 7 & Tape, rope and peg for land measurement and mapping out the land into pots. & 3.60 & 0.71 & 0.85 & NR, NS \\
\hline 8 & Watering can to take/supply water to Aloe Vera plants. & 3.07 & 0.85 & 0.82 & NR, NS \\
\hline 9 & Knapsack sprayer for spraying pesticides & 3.19 & 0.98 & 0.82 & NR, NS \\
\hline 10 & Knife and sickle for harvesting/cutting of Aloe Vera leaves. & 3.46 & 0.62 & 0.85 & NR, NS \\
\hline 11 & $\begin{array}{l}\text { Baskets, buckets, bowl and wheelbarrow for conveying Aloe Vera leaves to central } \\
\text { point on the farm. }\end{array}$ & 3.27 & 0.85 & 0.85 & NR, NS \\
\hline 12 & Polythene sacks to package Aloe Vera leaves. & 3.13 & 0.96 & 0.86 & NR, NS \\
\hline 13 & Scale machine to weigh Aloe Vera packs & 3.53 & 0.89 & 0.86 & NR, NS \\
\hline 14 & Books to record all transaction on Aloe Vera production farm. & 3.13 & 0.96 & 0.94 & NR, NS \\
\hline 15 & Tractor to convey Aloe Vera to the market and transport other farm implements. & 3.27 & 0.77 & 0.94 & NR, NS \\
\hline 16 & Juice extractor to extract Aloe Vera gel & 3.26 & 0.86 & 0.78 & NR, NS \\
\hline 17 & Rubber bowls to collect extracted juice & 3.20 & 1.05 & 0.78 & NR, NS \\
\hline
\end{tabular}

Note: $\mathrm{SD}=$ Standard Deviation, NR=Not Required, NS= Not Significant, $\mathrm{P} \leq 0.05, \mathrm{t}$-cri=1.96 Table 4: Mean rating and t-test analysis of respondents on the facilities required for training farmers in Benue state $(n=196)$

\begin{tabular}{|c|c|c|c|c|c|}
\hline S/NO & Evaluation techniques & Mean & SD & p-value & Remark \\
\hline 1 & $\begin{array}{l}\text { Visit farms and homes to assess } \\
\text { independent practice of Aloe Vera practice }\end{array}$ & 3.4 & 0.8 & 0.65 & NR, NS \\
\hline 2 & Written test & 3.13 & 0.89 & 0.66 & NR, NS \\
\hline 3 & Oral test & 3.2 & 1.05 & 0.98 & NR, NS \\
\hline 4 & $\begin{array}{l}\text { Practical exercise for observation by the } \\
\text { trainers }\end{array}$ & 3.46 & 0.81 & 0.98 & NR, NS \\
\hline 5 & $\begin{array}{l}\text { Group discussion to identifying areas of } \\
\text { difficulties }\end{array}$ & 3.53 & 0.81 & 0.93 & NR, NS \\
\hline 6 & structured interview & 3.47 & 0.89 & 0.93 & NR, NS \\
\hline 7 & Individual or group projects & 3.53 & 0.61 & 0.7 & NR, NS \\
\hline 8 & Material analysis & 3.26 & 0.86 & 0.69 & NR, NS \\
\hline 9 & Record analysis & 3.27 & 0.85 & 0.89 & NR, NS \\
\hline 10 & Questionnaire & 3.4 & 0.71 & 0.89 & NR, NS \\
\hline
\end{tabular}

Note: $\mathrm{SD}=$ Standard Deviation, NR=Not Required, NS= Not Significant, $\mathrm{P} \leq 0.05$, $\mathrm{t}$-cri=1.96

Table 5: Mean rating and t-test analysis of respondents on evaluation techniques for assessing farmers' achievement of objectives of aloe vera production in Benue state $(n=196)$.

the same is continued in subsequent years, suckers should be planted in July - August during monsoon season to get better field survival. This means that the items were content of aloe vera production manual for training farmers in aloe vera production in Benue state.

The findings of the study also revealed that, the facilities required for training farmers in aloe vera production include; cutlass for clearing of grasses and shrubs, pick axe for felling trees and stumping, rake for gathering of leaves, grasses and leveling seed beds, hoe for tilling and weeding of grasses, spade and digging fork to thrust vertically into soil, hand trowel, dibbler, jabstyle planters for transplanting and manure application, tape, rope and peg for land measurement, watering can to take/supply water to aloe vera plants, knife and sickle for harvesting/ cutting of aloe vera leaves, baskets, buckets, bowl and wheelbarrow for conveying aloe vera leaves to central point on the farm, tractor to convey aloe vera to the market and transport other farm implements, books to record all transaction on aloe vera production farm, polythene sacks to package aloe vera leaves. The findings were in agreement with the submission of Alaribe et al. [12] that, facilities for production of okro include: cutlass for clearing bush, cutting sticks, digging holes, weeding; hoe or making ridges, digging, weeding; spade for stumping of stems; tractor for ploughing, harrowing and ridging; baskets, had pans, buckets for carrying harvested fruits; knife for harvesting matured fruits. The findings were also in consonance with the position of [13], that the facilities for reengineering the teaching of clothing and textile practical components of the NCE in home economics curriculum includes: cutting tables, hand sewing machines, dry and steam iron, tape measures, rulers, ironing board, fabrics among others.

\section{Conclusion}

Crops do not only provide food for man, they also provide other opportunities such as employment and income generation. Aloe vera is one of those crops, but it seems most farmers lack entrepreneurial skills for its production that is why they don't produce it on commercial basis. This gap necessitated this study to develop an entrepreneurial skill manual that will be used in training farmers in aloe vera production. The study found 9 objectives for aloe vera production for farmers, 6 cluster items as the content of aloe vera manual for training farmers, 
Citation: Nongugwa DT, Asogwa VC (2017) Development of Entrepreneurial Skill Manual on Aloe Vera Production for Training Farmers in Benue State. Int J Waste Resour 8: 319. doi: 10.4172/2252-5211.1000319

8 methods of teaching for training farmers, 17 facilities for training farmers and 10 evaluation techniques for assessing farmers achievement of the objectives for aloe vera production.

\section{Recommendations}

Based on the results of the study, it was therefore recommended that:

1.Extension agents should regularly organize seminars and workshops for training of farmers and retraining of graduates to improve their technical efficiency using this manual.

2.Farmers should avail themselves for training in aloe vera production for proficiency.

3.Researchers should use the manual emanating from the study as a reference material for further research.

4.Researchers can use the manual developed for a needs assessment for aloe vera farmers in Benue State to establish areas of need in production.

\section{References}

1. Food and Agriculture Organization of the United Nations (2009) Definition and classification of commodities. Rome, Italy.

2. Manvitha K, Bidya B (2014) Aloe vera: A wonder plant its history, cultivation and medicinal uses. J Pharmacogn Phytochem 2: 85-88.

3. Food and Agriculture Organization (2002) Non-word forest products and nutrition, Rome, Italy.

4. Central Bank of Nigeria (2009) Annual report and statement of account for the year ended 31 December 2009.
5. Ogunbameru BO, UNdiandeye UC, Ani (2008) Agricultural extension technologies. Akani Publishers, Kaduna.

6. Asogwa VC, Lan MT, Olaitan SO (2014) Quality assurance of lecturers in agro-chimatology for effective teacher preparation in agriculture in colleges of education in south-east, nigeria. J Agric Home Econ Edu Res.

7. Rama BR, Etling AWW, Bowen BE (1993) Training of farmers and extension personnel. In: Samanta RK (ed.). Extension strategy for agricultural development in 21st century. Mittal Publications, New Delhi.

8. Wever DG (2014) Development of entrepreneurship skill training manual in poultry production for farmers in Benue State. Unpublished Ph.D thesis, University of Agriculture Makurdi, Nigeria.

9. Jones R (2003) Building a business plan for your farm: Important first steps. Prepared for the 2003 Risk and Profit Summer Conference Manhattan, Kansas.

10. Ugwoke EO, Onu FM, Agboeze MU, Asogwa VC (2013) Occupational competencies required by retirees in pawpaw production and marketing for sustainable livelihood in Enugu State, Nigeria. J Res Meth Edu 3:19-26.

11. Rajeswari MR, Umadevi C Sharmila, Pushpa R, Selvavenkadesh S, et al (2012) Alovera: The miracle plant its medicinal and traditional uses in India. $J$ Pharmacogn Phytochem 1: 118-124.

12. Alaribe MO, Igwe E, Olaitan SO (2013) Management of resource inputs into the production of okra for enhancing wealth creation capability of women in Agriculture in Benue State. J Niger Vocation Associat 18: 259-266.

13. Onweh NA (2013) Identification of facilities for reengineering the teaching of clothing and textile practical components of the NCE in home economics curriculum. J Niger Vocation Assoc 18: 87-95 